\title{
ОСОБЛИВОСТІ КОМУНІКАТИВНОЇ ВЗАЄМОДІЇ МЕДИЧНОЇ СЕСТРИ ТА ГЕРІАТРИЧНИХ ХВОРИХ
}

\author{
О. В. Іванчук, А. О. Боб \\ Бериславський медичний коледж \\ ДВНЗ «Тернопільський державний медичний університет \\ імені І. Я. Горбачевського МОЗ Украӥни»
}

Мистецтво спілкування є невід’ємною частиною діяльності медичної сестри, що потребує ретельного вивчення та постійного вдосконалення. Робота 3 геріатричними хворими потребує високого професіоналізму в сфері встановлення комунікативного зв’язку. Формування комунікативної культури майбутнього медика починається з ознайомлення із теоретичним матеріалом, вивчення правил етики та деонтології, а й своєчасного виявлення труднощів у професійному спілкуванні.

\section{FEATURES OF COMMUNICATIVE INTERACTION OF NURSE AND GERIATRIC PATIENTS}

\author{
O.V. Ivanchuk, A. O. Bob \\ Beryslav Medical College \\ I. Horbachevsky Ternopil State Medical University
}

The art of communication is an integral part of nursing that requires careful study and continuous improvement. Working with geriatric patients requires professionalism in the field of establishing communication links. Formation of communicative culture of the future physician begins with a review of theoretical material, learning the rules of ethics and deontology, but early detection of problems in professional communication.

Вступ. Спілкування між медичною сестрою та пацієнтом у наш час $є$ дуже актуальним питанням. Мистецтво спілкування $є$ невід'ємною частиною діяльності медичної сестри, тому потребує ретельного вивчення та постійного вдосконалення. Спілкуючись з іншими людьми, ми не тільки обмінюємося інформацією, досвідом, а й вчимося слухати та розуміти іншого.

При підготовці майбутніх молодших спеціалістів важливу роль відводять саме вивченню мистецтва спілкування, що $є$ необхідною частиною роботи на всіх етапах діагностичного, лікувального та реабілітаційного процесу. Особливо гостро проблема спілкування постає при роботі з геріатричними хворими. Дослідження кола спілкування людей похилого віку показує, що вони відчувають комунікативні труднощі, особливо при спілкуванні з новими людьми, важко знаходять порозуміння та схильні до конфліктів. Це вимагає від медичної сестри високого професіоналізму.

Було проведено тестування 32 студентів Бериславського медичного коледжу «Чи ефективно Ви

(C) О. В. Іванчук, А. О. Боб, 2017 спілкуєтесь?». Тест складався з 30 запитань про вміння спілкуватися, проявляти себе як слухач, що дуже важливо для професії медичної сестри.

Метою дослідження було провести аналіз впливу кваліфікованого медсестринського спілкування на якість догляду за геріатричними пацієнтами.

Основна частина. Актуальним завданням сьогодення $\epsilon$ удосконалення спілкування між медичною сестрою та пацієнтом. Розвиток комунікативних умінь і навичок та засвоєння мистецтва індивідуального підходу повинно відбуватися ще в стінах навчального закладу. Важливим елементом підготовки майбутніх спеціалістів є постійне вивчення та практичне засвоєння мистецтва спілкування. На кожному кроці свого навчання та подальшої професійної діяльності ми кожного разу чуємо про важливість дотримання етики та деонтології, налагодження психологічного клімату в контакті з пацієнтом, прояв терпіння та розуміння іншої людини.

Становище та роль медичної сестри набуває все більшого значення. $Є$. О. Климов відносить професію 
медичного працівника до типу професій «людиналюдина» [1]. Адже медсестринська діяльність нерозривно пов'язана з психологічними та емоційними чинниками, що відбуваються саме під час спілкування. Виконання медичних процедур та маніпуляцій відповідно до протоколів медичних сестер, що затверджені Міністерством охорони здоров'я завжди починаються з психологічної підготовки пацієнта, а отже, завданням медичної сестри $є$ не тільки бездоганне володіння практичними навичками, а й вміння встановити психологічний контакт за допомогою вербальних та невербальних засобів спілкування (правильно підібрані слова, міміка, жести, інтонація). Особливо гостро проблеми спілкування постають при роботі 3 людьми похилого віку [2]. Україна належить до країн із високою тенденцією старіння населення. Це зумовлює зростання потреб людей похилого віку в геріатричній допомозі, а отже, в підготовці висококомпетентних спеціалістів. Робота з цією категорією людей більш складна та має свої особливості, що зумовлені впливом хвороби на психологічний стан, функціональними змінами, психологічними особливостями.

Дослідження кола спілкування людей похилого віку показує, що контакти з молодими людьми не завжди бувають успішними, оскільки вони не завжди розуміють їхні проблеми та переживання. Внаслідок цього допомогу та розуміння багато людей похилого віку намагаються знайти в однолітках. Отримати співчуття можуть швидше в спілкуванні з людьми, які мають такий же життєвий досвід та стереотипи. У людей похилого віку виникають складнощі у формуванні нових особистісних контактів, що пояснюється тим, що літні люди відчувають комунікативні труднощі, важко знаходять спільну мову з новими людьми, ригідні у спілкуванні, відчувають боязнь бути незрозумілими, мають схильність до конфліктів [3]. Це вимагає від медичної сестри високого професіоналізму, адекватного сприйняття та розуміння. Тому ще з перших кроків до здобуття цієї благородної професії важливо своєчасно виховати не тільки такі етичні властивості, як обов'язок, совість, справедливість, а й вміння слухати, розуміти, проявляти співчуття, вміти аналізувати свою діяльність та себе як особистість. 3 цією метою серед студентів Бериславського медичного коледжу було проведено тестування «Чи ефективно Ви спілкуєтесь?». Тест складався з 30 запитань про вміння спілкуватися, проявляти себе як слухач, що дуже важливо для професії медичної сестри:

\begin{tabular}{|c|c|c|c|c|c|}
\hline \begin{tabular}{c|c} 
№ \\
$3 a / \pi$
\end{tabular} & $\begin{array}{l}\text { Характеристика процесу } \\
\text { спілкування } \\
\end{array}$ & $\begin{array}{l}\text { У більшості } \\
\text { випадків }\end{array}$ & Часто & Іноді & $\begin{array}{l}\text { Майже } \\
\text { ніколи }\end{array}$ \\
\hline 1 & $\begin{array}{l}\text { Чи намагаєтеся ви припинити розмову, коли тема чи } \\
\text { співрозмовник вам не цікаві? }\end{array}$ & 1 & 2 & 3 & 4 \\
\hline 2 & Чи дратує вас манера спілкування співрозмовника? & 4 & 3 & 2 & 1 \\
\hline 3 & Чи може невдалий вислів спровокувати вас на грубість? & 1 & 2 & 3 & 4 \\
\hline 4 & Чи перебиваєте співрозмовника? & 4 & 3 & 2 & 1 \\
\hline 5 & Чи робите вигляд, що слухаєте, а самі подумки десь далеко? & 4 & 3 & 2 & 1 \\
\hline 6 & $\begin{array}{l}\text { Чи змінюється тон, голос залежно від того, що говорить } \\
\text { співрозмовник? }\end{array}$ & 4 & 3 & 2 & 1 \\
\hline 7 & Чи виправляєте мовні помилки співрозмовника? & 4 & 3 & 2 & 1 \\
\hline 8 & $\begin{array}{l}\text { Чи висловлюєте ви подумки заперечення, поки співрозмовник } \\
\text { говорить? }\end{array}$ & 1 & 2 & 3 & 4 \\
\hline 9 & Чи буває у вас іронічний або з неповагою тон до співрозмовника? & 1 & 2 & 3 & 4 \\
\hline 10 & $\begin{array}{l}\text { Чи змінюєте ви тон, голос, вираз обличчя залежно від того, хто ваш } \\
\text { співбесідник? }\end{array}$ & 1 & 2 & 3 & 4 \\
\hline 11 & $\begin{array}{l}\text { Чи сприймаєте ви повідомлення цілком, у тому числі його словесне } \\
\text { і несловесне вираження? }\end{array}$ & 4 & 3 & 2 & 1 \\
\hline 12 & Чи визнаєте ви, що однакові слова для різних людей означають різне? & 4 & 3 & 2 & 1 \\
\hline 13 & $\begin{array}{l}\text { Чи прислухаєтеся ви тільки до того, що хочете почути, не } \\
\text { помічаючи решти? }\end{array}$ & 1 & 2 & 3 & 4 \\
\hline 14 & Чи дивитеся ви на того, хто говорить? & 4 & 3 & 2 & 1 \\
\hline 15 & Чи концентруєтеся ви на суті сказаного? & 4 & 3 & 2 & 1 \\
\hline 16 & $\begin{array}{l}\text { Чи відомо вам, на які слова і вирази ви найбільше реагуєте } \\
\text { емоційно? }\end{array}$ & 4 & 3 & 2 & 1 \\
\hline 17 & $\begin{array}{l}\text { Чи обмірковуєте ви заздалегідь, якої мети збираєтеся досягти в } \\
\text { даному акті спілкування? }\end{array}$ & 4 & 3 & 2 & 1 \\
\hline 18 & Чи плануєте ви час, коли краще висловити свою думку? & 4 & 3 & 2 & 1 \\
\hline 19 & Чи думаєте ви про те, як інша людина прореагує на сказане вами? & 4 & 2 & 3 & 1 \\
\hline
\end{tabular}


Продовження табл.

\begin{tabular}{|c|c|c|c|c|c|}
\hline $\begin{array}{c}\text { № } \\
3 a / \Pi \\
\end{array}$ & $\begin{array}{c}\text { Характеристика процесу } \\
\text { спілкування }\end{array}$ & $\begin{array}{l}\text { У більшості } \\
\text { випадків }\end{array}$ & Часто & Іноді & $\begin{array}{l}\text { Майже } \\
\text { ніколи }\end{array}$ \\
\hline 20 & $\begin{array}{l}\text { Чи враховуєте ви те, яким чином краще здійснити акт спілкування } \\
\text { (у письмовій чи усній формі, по телефону, за допомогою дошки } \\
\text { оголошень, записки тощо)? }\end{array}$ & 4 & 3 & 2 & 2 \\
\hline 21 & $\begin{array}{l}\text { Чи враховуєте ви, з якою людиною говорите (чимось } \\
\text { занепокоєною, вороже настроєною, незацікавленою, що поспішає, } \\
\text { сором'язливою, упертою, нетерплячою тощо)? }\end{array}$ & 4 & 3 & 2 & 1 \\
\hline 22 & Чи перебиваєте ви того, хто говорить? & 4 & 3 & 2 & 1 \\
\hline 23 & Чи думаєте ви іноді: «А я сподівався, що він це мав знати»? & 4 & 3 & 2 & 1 \\
\hline 24 & $\begin{array}{l}\text { Чи дозволяєте ви тому, хто говорить, виявляти негативне } \\
\text { ставлення до вас, не займаючи при цьому оборонної позиції? }\end{array}$ & 4 & 3 & 2 & 1 \\
\hline 25 & $\begin{array}{l}\text { Чи займаєтеся ви регулярними вправами для вдосконалення свого } \\
\text { вміння слухати? }\end{array}$ & 4 & 3 & 2 & 1 \\
\hline 26 & Чи робите ви записи «на пам'ять» («пам'ятки»)? & 4 & 3 & 2 & 1 \\
\hline 27 & Чи не відволікають вас сторонні звуки та шум? & 4 & 3 & 2 & 1 \\
\hline 28 & $\begin{array}{l}\text { Чи слухаєте ви того, хто говорить, не критикуючи його і не } \\
\text { обговорюючи? }\end{array}$ & 4 & 3 & 2 & 1 \\
\hline 29 & $\begin{array}{l}\text { Чи повторюєте ви отримані інструкції і повідомлення, щоб } \\
\text { переконатися, що ви їх правильно зрозуміли? }\end{array}$ & 4 & 3 & 2 & 1 \\
\hline 30 & $\begin{array}{l}\text { Чи висловлюєте ви своїми словами те, що на вашу думку, почуває } \\
\text { той, хто говорить? }\end{array}$ & 4 & 3 & 2 & 1 \\
\hline
\end{tabular}

Сума балів охарактеризовує рівень уміння спілкуватися: 110-120 - відмінно, 99-109 - вище середнього, 98-88 - нормально, 77-87 - посередньо.

Провівши тестування серед 32 студентів отримано такі результати: 10 студентів отримали відмінний ре- зультат (31,2 \%), 14 студентів отримали рівень вище середнього (43,8\%), 6 студентів отримали нормальний рівень (18,8 \%) та 2 студенти отримали посередній рівень $(6,2 \%)$ (рис).

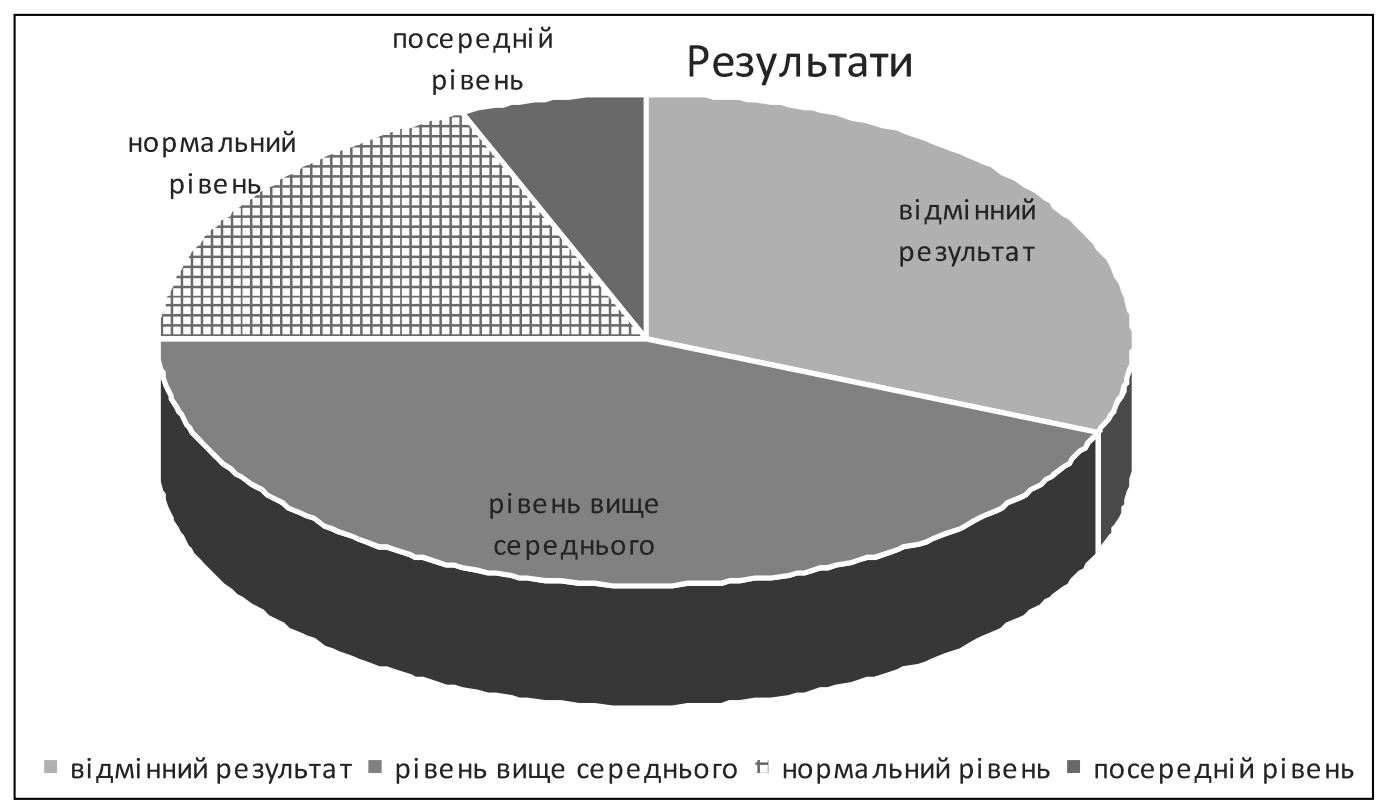

Puc. Результати тесту.

Даний тест дав змогу отримати уявлення студентам про себе як про слухача та співрозмовника, а також можливість проаналізувати свої помилки, щоб у подальшому над ними працювати.

Ефективність взаємодії між пацієнтом і медичною сестрою залежить від вміння правильно встановити психологічний контакт. Для попередження виникнення конфлікту потрібно володіти стриманістю та самоконтролем, вміти глибоко проаналізувати складну ситуацію, не проявляти агресію чи суперечливість. Важливо пояснити пацієнту, що в організації догляду та лікування ви маєте з ним спільну мету - покращен- 
ня здоров'я. При цьому важливо створювати довірливу атмосферу, проявляти щирість та зацікавленість в проблемах пацієнта.

Спілкування з геріатричними хворими не обмежується тільки психологічними особливостями. Потрібно також враховувати фізіологічні зміни, що відбуваються внаслідок процесу старіння. Майже у третини людей похилого віку є зміни слухової чутливості. Відбувається погіршення здатності вирізняти голоси чи звуки з-поміж інших шумів. У процесі старіння погіршується чутливість сприйняття окремих звуків мовлення, наприклад, таких, як «с», «ш», «ч» i «ф» [1]. Внаслідок процесу старіння людей похилого віку виникають різноманітні порушення зору. Частим порушенням є зниження гостроти зору. Воно пов'язане з погіршенням еластичності кришталика ока, а також відмиранням рецепторів сітківки [1]. Це значно ускладнює процес спілкування і вимагає від медичної сестри більших зусиль. При підготовці майбутніх спеціалістів важливу роль приділяють навчанню студентів підбирати індивідуальний підхід до пацієнтів залежно від віку, психологічних особливостей, фізіологічних змін. 3 цією метою студенти не тільки теоретично пізнають всі особливості спілкування з геріатричними хворими, а й практично втілюють свої набуті знання. На практичних заняттях майбутні спеціалісти мають змогу працювати з людьми похилого віку під чітким наглядом викладача та старшої медичної сестри.

\section{СПИСОК ЛІТЕРАТУРИ}

1. Поплавська С. Д. Етика професійної взаємодії медпрацівника і хворого / С. Д. Поплавська // Комп'ютерноінтегровані технології: освіта, наука, виробництво. - 2013. № 11.- С. 126.

2. Коляда Н. М. Соціальна геронтологія [Електронний ресурс] : навч.посіб. / Н. М. Коляда, Т. В. Коляда. - 2016. - № 1. - 84 c.
Завдяки цьому студенти мають змогу не тільки набиратися досвіду у медичних сестер, а й самостійно розвивати в собі комунікативні вміння. Під час роботи у відділенні майбутні спеціалісти можуть на власному досвіді пізнати всі особливості взаємодії між медичною сестрою та пацієнтом. Працюють 3 людьми з порушенням слуху та зору, що дає можливість самостійно вибрати спосіб передачі інформації після аналізу особливостей пацієнта. При проведенні бесіди проявляють не тільки тактовність, а й вміння підбирати правильні слова та поведінку в конфліктних ситуаціях. Під час таких практичних занять студенти краще засвоюють основні професійні якості медика та вдосконалюють уже сформовані навички.

Висновки. Спілкування з пацієнтом $\epsilon$ необхідним елементом догляду та лікування. Робота з геріатричними хворими не легка та потребує високого професіоналізму в сфері встановлення комунікативного зв'язку. Формування комунікативної культури медика повинно починатися ще з перших кроків навчання в медичних коледжах. Важливим елементом $\epsilon$ не тільки ознайомлення з теоретичним матеріалом, вивчення правил етики та деонтології, а й своєчасне виявлення труднощів у професійному спілкуванні. 3 цією метою важливо застосовувати різні види досліджень: проведення тестів, опитувань, спостережень за комунікативною діяльністю студента під час професійної діяльності. На сьогодні в еру нових сучасних технологій моральні якості медичного працівника залишаються в пріоритеті.

3. Пасєчко Н. В. Основи сестринської справи : підручник / Н. В. Пасєчко, М. О. Лемке, П. Є. Мазур. - Тернопіль : Укрмедкнига, 2002. - 544 с.

4. Касевич Н. М. Медсестринська етика і деонтологія : підручник / Н. М. Касевич. - 3-тє вид., випр. - К., 2013. 200 c. 